\title{
Living in discarded containers: spiders explore a new niche created by littering in urban woodlands
}

\author{
Krzysztof Kolenda ${ }^{1}$ (D) Konrad Wiśniewski ${ }^{2}$ (D) Krzysztof Kujawa ${ }^{3}$ (D) \\ Natalia Kuśmierek ${ }^{4}$ (iD $\cdot$ Adrian Smolis $^{5}$ (D) Marcin Kadej $^{5}$ (D)
}

Received: 17 November 2020 / Revised: 15 February 2021 / Accepted: 9 March 2021 /

Published online: 28 April 2021

(C) The Authors 2021

\begin{abstract}
Increased urbanisation is leading to littering of the environment. However, some animals may adapt to live in such altered habitats. The aim of this study was to assess whether discarded containers can serve as a suitable microhabitat for spiders. The study was conducted in 10 woodland areas in the city of Wrocław, Poland. In September 2018, a total of 939 containers were collected, of which $33.5 \%$ contained evidence of spiders having resided therein: webs, dead or living spiders, exuviae or cocoons. A total of 22 species and several other taxa that could not be recognised so accurately were detected. The most common of these belonged to Linyphiidae and Theridiidae. Juveniles $(\mathrm{N}=103)$ dominated over adults $(\mathrm{N}=58)$, and females $(\mathrm{N}=34)$ were more numerous than males $(\mathrm{N}=24)$. In 15 containers, interspecies pairs were found. Among ecological guilds, sheet web spiders dominated (60\%) followed by space web spiders (24\%), ground hunters $(9 \%)$, ambush hunters $(3 \%)$, specialists $(3 \%)$, and other hunters $(2 \%)$. Spiders were significantly more often found in colourless $(38.3 \%)$ and green (35.5\%) than in brown bottles $(25.2 \%)$. They were also more numerous in glass bottles for sweet drinks $(50.0 \%)$ than in beer bottles $(28.0 \%)$, and slightly more frequent than in glass vodka bottles $(33.3 \%)$. Our study showed that discarded containers are fully exploitable microhabitats for spiders and are used by these animals for at least three different purposes: hunting, hiding and breeding, however the effect on their fitness remains unknown.
\end{abstract}

Keywords Araneae $\cdot$ Ecological trap $\cdot$ Garbage $\cdot$ Microhabitat $\cdot$ Spider web $\cdot$ Urban forest

Communicated by Nigel E. Stork.

This article belongs to the Topical Collection: Urban biodiversity.

Marcin Kadej

marcin.kadej@uwr.edu.pl

Extended author information available on the last page of the article 


\section{Introduction}

Increased human activity leads to drastic changes in the environment. Through habitat alterations, environmental pollution, and the spread or creating dispersal routes for invasive species and diseases, urbanisation is considered as a major factor of biodiversity loss (Maxwell et al. 2016; Sol et al. 2017). While the intensity and universality of these declines remains under debate, due to limited data, populations and species of many taxa are declining, sometimes dramatically (Ceballos et al. 2017; Didham et al. 2020; Montgomery et al. 2020). Although most animals cannot cope with human-altered environments, many others persist and have adapted to new conditions, including those in urban areas (McKinney 2008). Certain factors that occur only in urban areas can create favourable conditions for ecologically flexible species (Tuomainen and Candolin 2011). These include high spatial habitat heterogeneity (i.e. 'urban mosaic', Sattler et al. 2010), with some new microhabitats (Bar-Ziv et al. 2018), a warmer climate enhanced by the urban heat island (Youngsteadt et al. 2016), and artificial light at night (Mammola et al. 2018).

Spiders are characterised by high ecological plasticity and, as key predators in the ecosystem, play a crucial role in natural and urban habitats (Turnbull 1973; Riechert 1974; McIntyre 2000; Kralj-Fišer and Schneider 2012). Their reaction on urbanisation is highly species specific and depends on the individual nature of the city. Many assemblages of orb weavers and ground-dwelling spiders react to urbanisation by a decrease in species richness and an increase in abundance of selected species (Johnson et al. 2012; Lowe et al. 2016). There are, however, examples of spiders becoming less abundant and their communities less species rich as urbanisation increases (Dahirel et al. 2017; Piano et al. 2020). The success of some spider species in urban habitats may depend on their particular traits (Dahirel et al. 2017), their belonging to different ecological groups and inhabiting different habitat types (Piano et al. 2020), adaptation to new habitats such as building facades for spinning webs (Samu et al. 2004), or availability of prey (Trubl et al. 2012; Lowe et al. 2016). Spiders inhabit various urban microhabitats such as man-made structures (buildings, bridges, etc.; Heiling 1999; Mammola et al. 2018), cemeteries (Buchholz et al. 2016; Kowarik et al. 2016), gardens (Burkman and Gardiner 2015), or parks (Lowe et al. 2016). It is also well known that some orb weavers and ground-dwelling species are attracted by artificial light, which is probably caused by high activity of invertebrates in the vicinity of lamps (Heiling 1999; Manfrin et al. 2017; Czaczkes et al. 2018; Mammola et al. 2018). Urban forests also provide a suitable habitat for many species. Indeed, Magura et al. (2010) and Horváth et al. (2012) found a higher diversity of ground dwelling spiders in urban forests in comparison to similar habitats in the suburban and rural areas, as a consequence of a high share of non-forest species therein. Thus, it seems that, in an urban matrix of various habitats, the number of xerophilous and light-preferring species penetrate from open habitats towards the more urbanised sites (Magura et al. 2010; Horváth et al. 2012; Möller et al. 2019).

Forests, especially those situated close to human settlements, are vulnerable to littering (Bartczak and Żylicz 2014). The commonly discarded items are beverage containers such as bottles and cans, which constitute a deadly trap for many small animals including mammals, reptiles, amphibians and invertebrates (e.g. Benedict and Billeter 2004; Poeta et al. 2015). Attracted by a smell of drink remains or decaying corpses, small-sized animals enter bottles or cans and cannot escape due to the slippery and wet walls. Kolenda et al. (2015) and Poeta et al. (2015) revealed that invertebrates were trapped in more than $40 \%$ of collected containers. Although, in the previous study, living arthropods were observed in the containers (Kolenda et al. 2015, 2020), to the best of our knowledge, there are no 
studies concerning the use of this putative new niche for spiders to prey on trapped invertebrates. Only Prestwich (1977) observed complete webs, moulted exoskeletons and adult spiders inside discarded bottles.

In 2018, we started an ongoing project that is focused on testing the ecological trap hypothesis in relation to discarded containers. We supposed that some animal groups (e.g. ants; Kolenda et al. 2020) can dwell and breed inside these containers for at least part of their life, however the exact effect on their fitness remains unknown. Therefore, we assumed that spiders may also use discarded containers for different purposes, such as foraging or reproducing. We hypothesised that the trapping of potential prey in such places may attract spiders to spin their webs inside, for capturing the lured insects, similarly to web building near artificial light source. Consequently, we assumed that not the active or ambush hunters, but the web-building species are the most common predators in this artificial microhabitat. Among them, females and juveniles should dominate, while males usually actively explore the area in order to find a mate (Burgess 1978). Alternatively, spiders could use the discarded containers simply as one of many shelters available in the forest litter, without any special preferences towards them. Thus, our research is the first step in exploring discarded containers as potential ecological traps for spiders. It will help in planning further research that assesses how these litter items influence spiders' fitness, data crucial for distinguishing the ecological traps (Hale and Swearer 2016).

\section{Material and methods}

\section{Material collection}

Spiders dwelling in discarded containers were studied in Wrocław (Poland). Ten forest patches were selected within the boundaries of the city. Total area of each site varies from 16 to 139 ha. The forests are located mainly in river valleys. Most of them are formed by oak-hornbeam and riparian habitats; however, some were strongly altered and remain under high human pressure. In September 2018, we collected uncapped, discarded containers along forest paths within a 10-m-wide transect starting from the entrance to the forest. If possible, we picked up around 100 containers per forest. In total 939 bottles or cans were sampled. The containers were secured against spillage and transported to the laboratory. Afterwards, the presence of spider webs was noted and the content of containers was analysed on a plastic tray in order to find living and dead spiders, as well as their exuviae and cocoons. These were identified to the lowest possible taxonomic level, and all taxa that were assigned at least to the family level were grouped according to ecological guilds, according to Cardoso et al. (2011). The only exception were three individuals of Pachygnatha listeri; although classified as orb-web, they abandon their webs as adults and migrate (Martin, 1978), exploring their environment in search of mating opportunities. Thus, we removed them from this analysis. The basis for species identification were keys by Nentwig et al. (2020) and Roberts (1987). Spider names are in accordance with the World Spider Catalog (2021).

As the overall number of dead spiders was low (see "Results" section) all individuals (alive and dead) were pooled in one dataset. Due to (i) the exploratory nature of the study, and (ii) a lack of knowledge about the effects of container features on the invertebrate occurrence and mortality, we intended to take into account a variety of their traits: capacity (CAP), opening diameter (DIA), material (MAT), presence of a neck (NECK), colour 
(COL), and original content (CON) (for details see Online Resource Table S1). These features can be considered as important for invertebrates as they seem to affect attractiveness (colour, material, size, content) as well as accessibility of the containers (size, presence on neck). However, due to (i) small sample size of some classes and (ii) overlapping of some variables (e.g. COL nested in MAT in the case of cans), for statistical analyses we used only selected variables, values of categorical variables, and variable sets (see Online Resource Table S1, S2 for details). The main criterion for including the data for the analyses was the material used in container production ("Plastic" or "Glass" or "Aluminium"). An additional criterion for COL and CON traits was the size of the subclass larger than 50. In the case of CON, the subclasses were unevenly represented between material types, and in some cases, the subclass size amounted to zero. For example, "vodka" (including other strong alcoholic drinks such as whiskey, bourbon, etc.) was not noted in plastic, while "water" was not noted in glass containers.

\section{Statistical analyses}

Chi-squared tests were used to: (i) compare the frequency of adult and juvenile individuals as well as females and males; (ii) test the differences in the frequency of spiders presence (webs, dead or living spiders, exuviae or cocoons) between the container classes as well as the differences in composition of the most numerous ecological guilds between the container classes. In cases where subclass size was smaller than five, Fisher's exact test was used. These analyses were carried out using Statistica 12 software (StatSoft Inc. 2014).

The dependency of spider presence and the dependency of spider guild representation on the container features were analysed with the use of multiple generalised linear models with binomial error frequency distribution, as well as logit link function. Due to the above mentioned limitation, linked with the small size of some subclasses, only a single categorical variable (each of four variables: MAT, NECK, COL, CON) and two numerical variables (CAP and DIA), together with the interactions between the categorical variable and each of two numerical variables were considered when building the models. For example, in the case of the material (MAT), five predicator variables were used for model building: MAT, DIA, CAP, MAT $\times$ DIA and MAT $\times$ CAP. We assumed the high homogeneity of the studied sites as the habitats were similar. Although spider species composition sometimes differs in particular sites even where the habitats are the same, we considered this heterogeneity of data should be much less pronounced as only the presence or absence of spiders, and the ecological groups are analysed. The best models were selected with the use of R package MuMIn (Barton 2016) by the corrected Akaike Information Criterion (AICc) (Burnham and Anderson 2004). When a subset of the best models consisted of more than one model matching the criterion $\Delta \mathrm{AICc}<2$ (the difference between the AICc of the best model and the AICc for each of the other models), the models were averaged with the use of package MuMIn. The significance of a model's coefficients was assessed with the aid of estimated statistical significance $(\mathrm{P})$ and $95 \%$ confidence intervals $(\mathrm{CI})$. In the case of averaged models, the number of best models ( $\mathrm{N}$ models) containing a given predictor was defined, as well as the relative variable importance (RVI) of the predictors being estimated. The analyses described in the paragraph were performed in the $\mathrm{R}$ environment ver. 3.5.2 ( $\mathrm{R}$ Core Team 2018). 
Fig. 1 Examples of containers utilised by spiders: a a glass bottle with Neriene clathrata (Linyphiidae) and its web, b a plastic bottle containing prey attached to the web

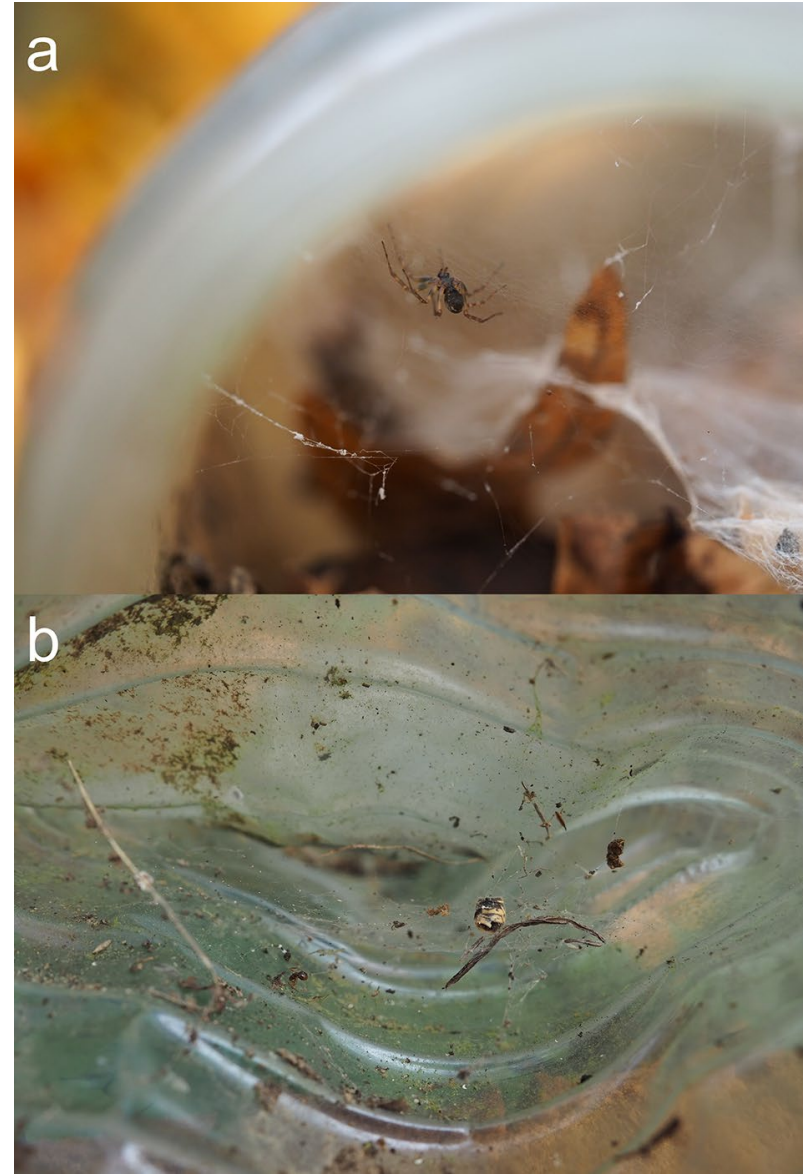

\section{Results}

\section{Spider composition found in containers}

We found evidence of spiders presence-webs, dead or living spiders, exuviae or cocoons-in 33.5\% $(\mathrm{N}=315)$ of all collected containers $(\mathrm{N}=939)$ (Fig. 1). Webs were the most common proof of the occurrence of spiders in bottles or cans; they were found in $30.9 \%$ of samples $(\mathrm{N}=290)$. However, only $40.7 \%$ of these $(\mathrm{N}=118)$ also contained spiders. In general, a total of 182 spiders have been found in $15.5 \%$ of containers $(\mathrm{N}=146)$, including 163 alive and 19 dead individuals (Online Resource Table S3). Additionally, a total of 26 exuviae and 2 cocoons were found in 22 and 2 containers, respectively (Online Resource Table S3). In two cases, the exuviae and spider from the same container belonged to the same species, thus we assumed that they represent one individual, which was taken into account in further analysis.

Except for 6 spiders and 9 exuviae, the other specimens or traces of spiders were classified at least to the family level. The most common were Linyphiidae and Theridiidae, which were represented by 113 and 43 individuals, respectively (including living or dead spiders, 


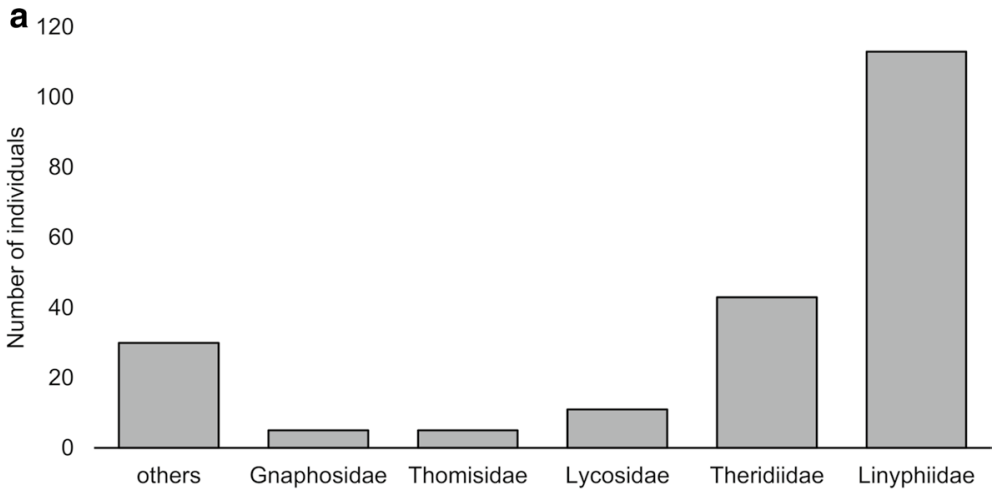

$\mathbf{b}_{120}$

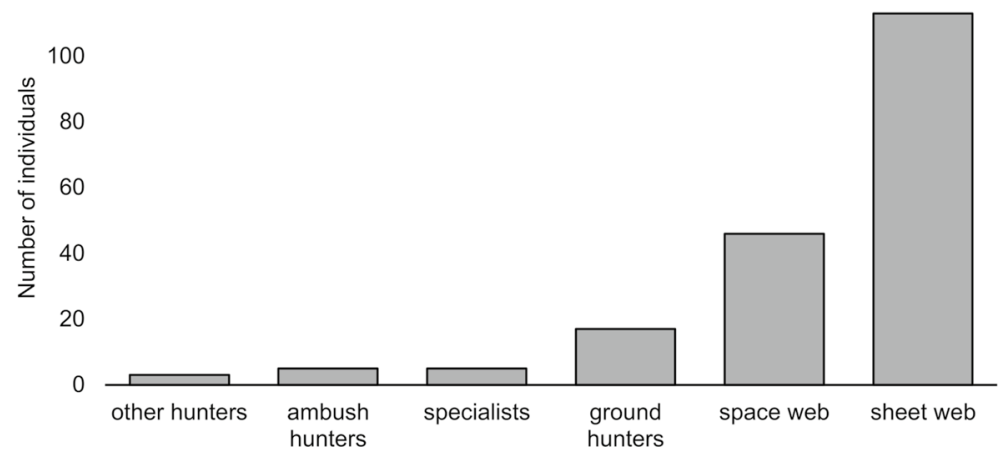

Fig. 2 Number of individuals found in discarded containers according to: a families (others include individuals not identiied to family level or families represented by less than 5 individuals). Exuviae and cocoons are also included; $\mathbf{b}$ guilds (Cardoso et al. 2011)

Fig. 3 Comparison of developmental stage and sex rate for collected spiders
120

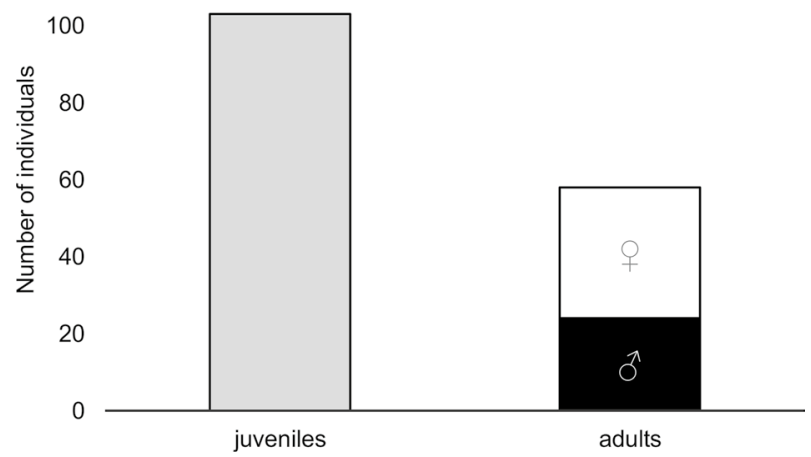

exuviae, and cocoons) (Fig. 2a). Among Linyphiidae, Tenuiphantes spp. dominated, while Enoplognatha spp. were the most numerous theridiid spiders (Online Resource Table S3). Remaining individuals were classified to 11 different families, which were represented by 
Table 1 Comparison of the number and percentage of containers with and without spiders (including webs, cocoons, exuviae), and statistical significance of the difference in relation to container feature

\begin{tabular}{|c|c|c|c|c|c|c|c|}
\hline & \multicolumn{2}{|c|}{ Present } & \multicolumn{2}{|c|}{ Absent } & \multirow[t]{2}{*}{$X^{2}$} & \multirow[t]{2}{*}{$\mathrm{df}$} & \multirow[t]{2}{*}{$\mathrm{P}$} \\
\hline & $\mathrm{N}$ & $\%$ & $\mathrm{~N}$ & $\%$ & & & \\
\hline \multicolumn{8}{|l|}{ Material } \\
\hline Aluminium & 48 & 32.9 & 98 & 67.1 & \multicolumn{2}{|l|}{1.73} & \\
\hline Glass & 197 & 32.5 & 409 & 67.5 & & 2 & $0.43(\mathrm{C})$ \\
\hline Plastic & 70 & 37.6 & 116 & 62.4 & & & \\
\hline \multicolumn{8}{|c|}{ Presence of neck } \\
\hline Yes & 186 & 32.9 & 380 & 67.1 & \multirow[t]{2}{*}{0.64} & \multirow[t]{2}{*}{1} & \multirow[t]{2}{*}{$0.42(\mathrm{C})$} \\
\hline No & 81 & 35.8 & 145 & 64.2 & & & \\
\hline \multicolumn{8}{|l|}{ Bottle colour } \\
\hline Colourless & 136 & 38.2 & 220 & 61.8 & \multirow[t]{3}{*}{11.3} & \multirow[t]{3}{*}{2} & \multirow[t]{3}{*}{$0.003(\mathrm{C})$} \\
\hline Brown & 59 & 25.0 & 177 & 75.0 & & & \\
\hline Green & 61 & 34.7 & 115 & 65.3 & & & \\
\hline \multicolumn{8}{|c|}{ Plastic bottle colour } \\
\hline Colourless & 56 & 38.1 & 91 & 61.9 & \multirow[t]{3}{*}{2.36} & 2 & \multirow[t]{3}{*}{$0.36(\mathrm{~F})$} \\
\hline Brown & 1 & 16.7 & 5 & 83.3 & & & \\
\hline Green & 2 & 20.0 & 8 & 80.0 & & & \\
\hline \multicolumn{8}{|c|}{ Glass bottle colour } \\
\hline Colourless & 80 & 38.3 & 129 & 61.7 & \multirow[t]{3}{*}{9.43} & 2 & \multirow[t]{3}{*}{$0.009(\mathrm{C})$} \\
\hline Brown & 58 & 25.2 & 172 & 74.8 & & & \\
\hline Green & 59 & 35.5 & 107 & 64.5 & & & \\
\hline \multicolumn{8}{|c|}{ Original content of plastic containers } \\
\hline Sweet drinks & 29 & 43.9 & 37 & 56.1 & \multirow[t]{3}{*}{5.11} & 2 & \multirow[t]{3}{*}{$0.09(\mathrm{~F})$} \\
\hline Water & 25 & 34.2 & 48 & 65.8 & & & \\
\hline Beer & 0 & 0.0 & 6 & 100.0 & & & \\
\hline \multicolumn{8}{|c|}{ Original content of glass containers } \\
\hline Sweet drinks & 19 & 50.0 & 19 & 50.0 & \multirow[t]{3}{*}{8.43} & 2 & \multirow[t]{3}{*}{$0.01(\mathrm{C})$} \\
\hline Beer & 115 & 28.0 & 296 & 72.0 & & & \\
\hline Vodka & 34 & 33.3 & 68 & 66.7 & & & \\
\hline
\end{tabular}

$\mathrm{X}^{2}$ Chi-square value, $d f$ degrees of freedom, $P$ statistical significance in the Chi-square test $(\mathrm{C})$ or exact Fisher's test $(\mathrm{F})$

11 or less individuals (see Online Resource Table S3 for a detailed list of spiders, their exuviae and cocoons).

Ecological guilds were assigned for 189 spiders, including the exuviae and cocoons. The most common were sheet web $(60 \%)$ and space web spiders $(24 \%)$, followed by ground hunters (9\%), ambush hunters (3\%), specialists (3\%), and other hunters (2\%) (Online Resource Table S3, Fig. 2b).

Sex or developmental stage could be determined for 161 individuals (Online Resource Table S3, Fig. 3). Juveniles $(\mathrm{N}=103)$ dominated over adults $(\mathrm{N}=58)\left(\mathrm{X}^{2}=25.2\right.$, df $=1$, $\mathrm{p}<0.001)$ but females $(\mathrm{N}=34)$ were not significantly more frequent than males $(\mathrm{N}=24)$ $\left(\mathrm{X}^{2}=3.5, \mathrm{df}=1, \mathrm{p}=0.06\right)$.

Most containers contained only one individual; however, in four cases, we found two or more spiders: (i) Tenuiphantes spp. female and juveniles, (ii) T. flavipes male and juveniles, (iii-iv) T. flavipes female and a juvenile. Additionally, there were 15 interspecies pairs found in a single container (Online Resource Table S4). 
Table 2 Averaged models of relationships between the presence of spiders in containers with six predictors (container features): four categorical predictors-material (MAT), presence of neck (NECK), colour (COL) and contents $(\mathrm{CON})$, and two numeric predictors - capacity (CAP) and opening diameter (DIA)

\begin{tabular}{|c|c|c|c|c|c|c|c|}
\hline & RVI & No. of models & Predictor level & Coefficient & CI-Min & CI-Max & $\mathrm{P}$ \\
\hline Intercept & & & & 0.078 & -2.478 & 2.634 & 0.952 \\
\hline CAP & 0.70 & 2 & & -0.002 & -0.007 & 0.004 & 0.435 \\
\hline \multirow[t]{2}{*}{ MAT } & 0.62 & 2 & MAT="glass" & -1.275 & -3.312 & 1.735 & 0.374 \\
\hline & & & MAT = "plastic" & -1.049 & -3.090 & 1.793 & 0.468 \\
\hline \multirow[t]{2}{*}{$\mathrm{MAT} \times \mathrm{CAP}$} & 0.32 & 1 & MAT = "glass" & 0.005 & -0.004 & 0.007 & 0.020 \\
\hline & & & MAT = "plastic" & 0.005 & -0.004 & 0.007 & 0.016 \\
\hline Intercept & & & & -1.080 & -1.824 & -0.335 & 0.004 \\
\hline CAP & 0.28 & 1 & & 0.000 & -0.001 & 0.001 & 0.700 \\
\hline NECK & 1.00 & 2 & NECK = "yes" & 0.758 & -0.027 & 1.544 & 0.059 \\
\hline Intercept & & & & -1.100 & -1.487 & -0.713 & 0.000 \\
\hline CAP & 0.27 & 1 & & 0.000 & 0.000 & 0.001 & 0.845 \\
\hline \multirow[t]{2}{*}{$\mathrm{COL}$} & 1.00 & 2 & $\mathrm{COL}=$ "colourless" & 0.612 & 0.200 & 1.023 & 0.004 \\
\hline & & & $\mathrm{COL}=$ "green" & 0.491 & 0.054 & 0.927 & 0.028 \\
\hline Intercept & & & & -0.783 & -1.322 & -0.244 & 0.004 \\
\hline CAP & 0.39 & & & 0.001 & -0.001 & 0.001 & 0.287 \\
\hline \multirow[t]{2}{*}{$\mathrm{CON}$} & 1.00 & & $\mathrm{CON}=$ "beer" & -0.111 & -0.590 & 0.368 & 0.650 \\
\hline & & & $\mathrm{CON}=$ "sweet" & 0.697 & -0.064 & 1.457 & 0.073 \\
\hline
\end{tabular}

$R V I$ relative variable importance, $C I 95 \%$ confidence intervals

\section{Spiders in relation to container features}

Spiders were present in 0-50\% of the containers within each container category (Table 1). A statistically significant effect was found for glass bottle colour $\left(X^{2}=9.43, \mathrm{df}=2\right.$, $\mathrm{p}=0.009)$. Spiders occupied colourless $(38.3 \%)$ and green $(35.5 \%)$ bottles more frequently than brown ones $(25.2 \%)\left(\mathrm{X}^{2}=8.67, \mathrm{df}=1, \mathrm{p}=0.003\right.$, and $\mathrm{X}^{2}=4.94, \mathrm{df}=1, \mathrm{p}=0.02$, respectively), but no significant difference was found between colourless and green bottles $\left(\mathrm{X}^{2}=0.30, \mathrm{df}=1, \mathrm{p}=0.59\right)$. Another significant effect occurred in the case of CON analysis $\left(\mathrm{X}^{2}=8.43, \mathrm{df}=2, \mathrm{p}=0.015\right)$, here spiders were recorded more frequently in glass bottles for sweet drinks $(50.0 \%)$ than in beer bottles $(28.0 \%)$, and slightly more frequent than in vodka glass bottles $(33.3 \%)\left(X^{2}=8.06, d f=1, p=0.005 ; X^{2}=3.27, d f=1, p=0.07\right.$; respectively). No significant relationship was found between beer and vodka glass bottles $\left(\mathrm{X}^{2}=1.14, \mathrm{df}=1, \mathrm{p}=0.29\right.$, respectively).

When considering ecological guilds in relation to container features, no container features significantly influenced the frequency of particular guilds (Online Resource Table S5).

In multivariable analysis for the presence of spiders in relation to container features, among the numeric features only CAP was present in some of the best models (5/9), categorical variables were present in all but one model, and interactions between numeric and categorical variables were absent with one exception (MAT $\times$ CAP) (Online Resource Table S6). The categorical effects were more significant (in terms of RVI, P, and N models) in the averaged models (Table 2). Spider presence in containers was positively (with marginal statistical significance) affected by NECK, by green or colourless glass (when 
Table 3 Averaged models of relationships between the presence of web spider guild (space vs. sheet web) in containers with six predictors (container features): four categorical predictors-material (MAT), presence of a neck (NECK), colour (COL) and contents (CON), and the two numeric predictors-capacity (CAP) and opening diameter (DIA)

\begin{tabular}{|c|c|c|c|c|c|c|c|}
\hline & RVI & No. of models & Predictor level & Coefficient & CI-Min & CI-Max & $\mathrm{P}$ \\
\hline Intercept & & & & 3.283 & -0.783 & 9.284 & 0.155 \\
\hline CAP & & & & -0.009 & -0.021 & 0.000 & 0.073 \\
\hline MAT (glass) & & & & -2.265 & -8.423 & 2.129 & 0.355 \\
\hline MAT (plastic) & & & & -5.641 & -11.905 & -1.141 & 0.025 \\
\hline $\begin{array}{l}\text { MAT } \\
\quad(\text { glass }) \times \text { CAP }\end{array}$ & & & & 0.005 & -0.005 & 0.017 & 0.385 \\
\hline $\begin{array}{l}\text { MAT (plas- } \\
\text { tic) } \times \text { CAP }\end{array}$ & & & & 0.010 & 0.001 & 0.023 & 0.045 \\
\hline Intercept & & & & -1.127 & -2.739 & 0.485 & 0.171 \\
\hline CAP & 0.72 & 2 & & 0.000 & -0.001 & 0.002 & 0.740 \\
\hline NECK & 0.73 & 2 & NECK = "yes" & 1.732 & -1.766 & 4.300 & 0.270 \\
\hline $\mathrm{NECK} \times \mathrm{CAP}$ & 0.45 & 1 & NECK = "yes" & -0.005 & -0.007 & 0.003 & 0.041 \\
\hline Intercept & & & & -1.371 & -2.641 & -0.100 & 0.034 \\
\hline CAP & 0.48 & 1 & & 0.000 & -0.001 & 0.001 & 0.960 \\
\hline \multirow[t]{2}{*}{$\mathrm{COL}$} & 0.52 & 1 & $\mathrm{COL}=$ "colourless" & 0.950 & -0.850 & 1.837 & 0.166 \\
\hline & & & $\mathrm{COL}=$ "green" & 0.779 & -0.885 & 1.693 & 0.290 \\
\hline Intercept & & & & -0.693 & -1.748 & 0.253 & 0.166 \\
\hline CON (beer) & & & & -0.503 & -1.649 & 0.703 & 0.395 \\
\hline CON (sweet) & & & & 0.511 & -1.044 & 2.081 & 0.515 \\
\hline
\end{tabular}

$R V I$ relative variable importance, $C I 95 \%$ confidence intervals

compared to brown) and by sweet contents (when compared to beer or vodka, but with marginal statistical significance). These effects, however, were present in the models with very poor Goodness-Of-Fit as reflected by low values of Nagelkerke- $\mathrm{R}^{2}$, amounting to $0.000-0.026$.

In the analysis of the effect of container features on the representation of spider guilds (sheet vs. space web spiders were only analyzed), one numeric variable (CAP) was also present in the best models (4/7) besides categorical variables (5/7) (Online Resource Table S7). In the averaged models (Table 3), the presence of sheet web spiders was affected negatively by plastic containers, however at a positive interaction MAT (plastic) $\times$ CAP. In the case of other categorical variables, most effects in the averaged models were insignificant with exception of the negative interaction NECK $\times$ CAP. Also, Goodness-of-Fit of these models was poor. The Nagelkerke- $\mathrm{R}^{2}$ amounted to $0.000-0.130$ in individual best models (Table S7), which indicates a weak predictive ability of these models. 


\section{Discussion}

\section{Ecological significance of discarded containers}

This study revealed that discarded containers are frequently dwelled by various groups of spiders. Detailed discussion with previous results is hardly possible because there is almost no research that shows influence of discarded containers on arthropod populations or communities. However, in contrast to our recent findings on ants (Kolenda et al. 2020), the containers serve for spiders more as an artificial microhabitat than as a deadly trap. Indeed, the number of containers with dead specimens was very low (1.7\% of all), especially in contrast to ants $(10.3 \%$ of containers with dead workers, and only $4.4 \%$ used as a nest; for details see Kolenda et al. 2020). Moreover, Lavers et al. (2020) found that discarded plastic bottles are a lethal trap for crabs on beaches, while Kolenda et al. (2015) and Poeta et al. (2015) noted mostly dead beetles and molluscs inside containers collected from suburban forests and sandy coastal dunes, respectively. Discarded containers can, however, act as suitable habitat for animals in aquatic conditions. In a lowland dam reservoir, macroinvertebrates diversity found in the bottles was as high as on phytolittoral bottom and higher than on other natural or artificial studied substrates (Czarnecka et al. 2009). Probably such items provided shelter against harsh environmental conditions of the near-shore zone of the reservoir (Czarnecka et al. 2009).

Some spider traits may explain why they did not die so often in the garbage traps but rather inhabited them, even if the containers were not dry. Many spiders readily walk on steep surfaces due to some adhesive structures (the so-called scopulae in wandering spiders) and support themselves with security threads in case they fall down. Many of them walk quite easily on the surface of water using surface tension; they may, in fact, use numerous techniques to move on liquid surfaces (Stratton et al. 2004). Similarly, some Linyphiid species easily avoid being trapped and readily walk on steep walls of pitfall traps (Topping 1993) and even build webs within (so exploring artificial habitats similar to the containers we studied). As predators, the spiders seem also not to be lured into the traps by the water and decaying matter, as some beetles or small mammals are (Benedict and Billeter 2004; Kolenda et al. 2015).

We observed that spiders which dwell in discarded containers use them for at least three different purposes: hunting, hiding, and breeding. As a confirmation of the latter, we found adult couples and cocoons. The only cocoons we found belonged to Ero spp., which are commonly found in European forests where they are attached to plants (Finch 2005a), e.g. to tree trunks. Their presence in containers can be additionally explained by the fact that Ero are small predators of the web spiders, using aggressive mimicry for hunting spiders sitting in webs (Czajka 1963). Discarded containers are also a presumably convenient moulting place for several spider families, even those that we did not record from live specimens; for instance, Gnaphosidae. This shows that containers serve as hiding places for some wandering spiders. However, this role cannot be overestimated, as spiders can use any shelter places in the forest litter. They may also serve as a hunting site for some spiders. Many studies have shown that prey availability is often crucial for spiders locating their webs on a site (e.g. Samu et al. 1996; Harwood et al. 2003; see also Wise 1993). Nearly $1 / 3$ of collected containers contained webs. In many randomly checked containers in the field, we found prey remains in these webs (Fig. 1b).

Despite the observation of various life stages and low mortality of spiders, as well as the fact that the containers are used by spiders for different purposes, we cannot conclude that 
they are a suitable habitat for these arthropods. Further studies comparing reproductive and hunting success, or species richness and specimen number in the containers and in their surroundings are necessary. This could explain which species of spiders avoid containers and which of them take any advantage of inhabiting the containers or fall into ecological trap.

The presence of more than one web in a single container does not necessarily mean that each of them was built by a single spider. As the example of Tenuiphantes tenuis shows, one specimen may build several webs and one web may be used by several specimens consecutively (Samu et al. 1996). The web spinners are often characterised by a kind of 'floating populations' (as shown by a sheet-web spider Linyphia triangularis; Toft 1998), due to frequent web takeover and the fact that empty webs are often colonised. We assume that this could be the case with some of the observed species. We cannot also exclude the occurrence of competition between spiders within the containers. In several cases, we have observed inter- and intraspecies pairs of spiders inhabiting one container. Some studies reported a high level of competition for web sites in the field (Samu et al. 1996; Heiling and Herberstein 1999; Riechert and Hall 2000; Hardwood et al. 2003). Related linyphiid spiders often have very similar niche preferences (e.g. a preference for web positioning; Toft 1987). Some observations showed that it is a common phenomenon that a heavier or larger spider overtakes the web (Samu et al. 1996; Eichenberger et al. 2009) and intraguild predation is also present among spiders (Finke and Denno 2002). Small linyphiid spiders may not be deterred from entering the site even in the presence of chemical clues from the larger spider predator (Wetter et al. 2012). However, some data shows that smaller spiders avoid places with the scent (the kairomons) of a larger spider predator (Persons and Rypstra 2001).

The open question is whether the containers provide conditions suitable for overwintering. Generally, in temperate zones, arthropods are prone to mortality due to low temperature; thus, they overwinter in habitats with stable conditions (Roume et al. 2011). Some, however, present adaptations to survive and are active even at temperatures below freezing-especially when prey is available (Aitchison 1984; Korenko et al. 2010; Lee 2012). Forests are important overwintering habitats for arthropods. Some species, including those found in our study (e.g. belonging to genera Enoploghatha, Neriene), overwinter in litter (Martyniuk and Wise 1985; Nähring 1991). Furthermore, whole season observations are required to assess if containers are left by spiders before winter or pose a year-round habitat.

\section{Fauna overview-species filtering and biases}

We recorded an array of typical litter- and undergrowth-dwelling species of the forest litter of the European temperate zone (Stańska et al. 2002; Finch 2005b; Milasowszky et al. 2015; Košulič et al. 2016), but only three of them dominated. The most dominant spider of these "garbage-assemblages" was Tenuiphantes flavipes, a very common species from Linyphiidae, which predominantly lives on the ground surface in different woodlands (Hänggi et al. 1995) where it builds small sheet webs. The species has a slight preference for shade and a stronger one for moist habitats (Entling et al. 2007) but its niche preferences and the habitats it utilises are broad (Hänggi et al. 1995; Entling et al. 2007). We observed the dominance both of the juveniles (not identified with certainty, but many of them most probably belonged to this species) and of adult 
specimens. This species builds webs for hunting and mating; we, therefore, suppose that it explores the garbage for both purposes.

The second most common spider was Enoplognatha spp., most probably E. ovata, which is confirmed by habitat type (Oxford 1992; Barthel 1997) and the presence of an adult specimen. This spider builds webs in the understory of different habitats, including forests, and prefers dense vegetation. This refers, however, to the adult specimens and not necessarily to the juveniles-spiders may shift microhabitats with successive life stages. The juveniles, which predominated in our samples, are known to overwinter in litter and disperse in spring into higher strata of the understory (Nähring 1991). A similar rule most likely pertains to other relatively big species of Linyphiidae, such as Neriene clathrata or Linyphia hortensis, which are common in our samples. For instance, Neriene clathrata generally weaves its sheet web in the lower strata of forest undergrowth (Wright and Coyle 2000).

When considering guild composition, there were hardly any ground or ambush hunters in the containers; however, we noticed some signs of their presence (the exuviae) and a few dead specimens belonging to these ecological groups. The wolf spiders (Lycosidae) are known to have a 'sit-and-move' strategy of exploring prey in their environment (Samu et al. 2003). Therefore, we suppose that they may be only the temporary visitors of containers, performing in this case a 'come-and-go' strategy. The predominance of sheet and space web weavers in our samples may result from the fact that these groups may easily adapt to structural properties of habitats and spend more time in discarded containers while waiting for their prey or while mating. Some of them even enlarge their webs with time by overbuilding the older parts of their snare (Benjamin and Zschokke 2004).

Without comparative study of species from the surroundings, we cannot precisely determine if the dominance of spider species in the containers results from their high abundance in the environment or from some species filtering towards the new microhabitat. Moreover, a total of 22 species and several further taxa that could not be recognised so accurately is a low number for typical temperate forests (Scharff et al. 2003; Stańska et al. 2016), which may reach about 80 for a sampling plot when sampled extensively (Scharff et al. 2003). However, the intensity of sampling and the used method was different in the studies, so our data are hardly comparable. The environmental factors, which influence richness and composition of forest spider assemblages, are the canopy cover, humidity, litter structure, and plant structure and density (Bultman and Uetz 1982; Samu et al. 1996; Pearce et al. 2004; Entling et al. 2007; Oxbrough et al. 2010); however, they were not considered in this study.

It should be also noted, that other factors can affect species richness. For instance, each sampling method used in arthropod studies is somehow biased (Topping and Sunderland 1992; Prasifka et al. 2007). Typical for the pitfall traps is a high dominance of spiders belonging to Lycosidae, the large ground hunters, which-along with some other families of wandering spiders - are very active and, as a result, dominate the yield of pitfall traps (Uetz and Unzicker 1976). On the contrary, this family was hardly present in our samples and recorded from dead specimens (or exuviae). The sampling period is also important. Spiders show a strong pattern in their phenology (e.g. Riecken 1999; Hsieh and Linsenmair 2012; Blandenier et al. 2013). Our study was conducted in September and the highest species richness is recorded in spring and early summer (Niemelä et al. 1994).

The other factor which we did not consider is spiders' circadian activity (see Krumpálová and Tuf 2013 for data from central European forests). Some hunters which are active during the day time may have been absent in our samples as we sampled the containers during those hours. Thus, we do not claim that our list covers the whole diversity of spiders being entrapped or utilising the litter left over in the forests. 


\section{Preferences toward containers}

Spiders are the generalist terrestrial predators which explore every possible space niche that is suitable for them to forage or breed. Our results indicate that there was no clear preference of spiders for any type of discarded containers. One of the exceptions was the low preference towards brown glass bottles and those containing beer or high-volume alcohol. This result should be treated with caution, as it is very hard to relate it to spider biology and the sample size was small in some subclasses. More data and further (meta)analysis could probably show clear preferences of spiders towards container types. We assume that there might be some preferences, based on studies analyzing efficiency of pitfall traps that are used in ecological studies. Methodological works on the construction of pitfall traps suggest that spiders catching rate may vary depending on their features. Namely, the effectiveness of these traps might be affected by the presence or absence of covers (Buchholz and Hanning 2009), the colour of traps (Buchholz et al. 2010), the entrance size (Work et al. 2002) or properties of fluid inside the container (Pekár 2002; Schmidt et al. 2006). Therefore, we had anticipated some bias in the number of spiders according to specific container categories.

The other factor that might have influenced spiders could be the shape of the containers, which we did not analyse, because web-building spiders are dependent on the availability of sites for spinning their snare. On the other hand, the linyphiids may also easily adapt the shape of their webs to the available spatial conditions (Samu et al. 1996; Rybak 2007). The position of the container opening could also be significant, because forest litter is not a single layer-it is a diversified three-dimensional space which creates several microhabitats for spiders (Wagner et al. 2003) and some spiders may even migrate into very deep soil layers (Laška et al. 2011). However, the lack of any explicit influence of container features on spiders, suggests that these animals - in contrast to many other arthropod groups-may not be attracted to them and simply exploit every available microhabitat of the forest litter.

\section{Conclusions}

The goal of our research was to present another example of wildlife adapting to life in a human-modified environment. Beverage containers are a common litter items in land and aquatic environments around the world (Roman et al. 2020; Kolenda et al. 2021). They may become fully exploitable (micro)habitats for some spiders. However, further studies, i.e. concerning presumptive overwintering or hunting and reproductive success, should explain if containers are really a favourable habitat for them or constitute an ecological trap for spiders.

Despite potential positive effect on some selected spider and ant populations, it should be noted that discarded containers do not promote rare species and act as lethal trap for other arthropod groups and small vertebrates (Benedict and Billeter 2004; Kolenda et al. 2015, 2020; Poeta et al. 2015; Lavers et al. 2020). As our recent study showed, bottles and cans are also a threat for medium size animals such as deer, red foxes or weasels (Kolenda et al. 2021). Moreover, such microhabitats favour the spread of the yellow fever mosquito, Aedes aegypti-a dengue vector (Juarez et al. 2020). Therefore, as a significant threat to ecosystems, they should be regularly removed from the environment. 
Supplementary Information The online version contains supplementary material available at https://doi. org/10.1007/s10531-021-02160-4.

Acknowledgements We thank Katarzyna Bąbalska, Weronika Wilczyńska, and Kacper Pilarczyk, members of the student research club at the University of Wrocław, for their help during laboratory work. We also thank Dr. Deborah Harvey (Royal Holloway, University of London, UK) for language corrections. Constructive remarks made by Associate Editor and anonymous reviewer greatly improved the manuscript.

Author contributions Conceptualization and methodology: KKol, KKuj, NK, AS, MK, Material collection and data analysis: KKol, KW, KKuj, NK, AS, MK, Writing-original draft preparation: KKol, KW; Writing-review and editing: KKuj, NK, AS, MK.

Funding This research did not receive any specific grant from funding agencies in the public, commercial, or not-for-profit sectors.

Data availability The datasets generated and analysed during the current study are available from the corresponding author on reasonable request.

\section{Declarations}

Conflict of interest All the authors declare that they have no conflict of interest.

Consent to publish All authors consent to publication of this manuscript.

Open Access This article is licensed under a Creative Commons Attribution 4.0 International License, which permits use, sharing, adaptation, distribution and reproduction in any medium or format, as long as you give appropriate credit to the original author(s) and the source, provide a link to the Creative Commons licence, and indicate if changes were made. The images or other third party material in this article are included in the article's Creative Commons licence, unless indicated otherwise in a credit line to the material. If material is not included in the article's Creative Commons licence and your intended use is not permitted by statutory regulation or exceeds the permitted use, you will need to obtain permission directly from the copyright holder. To view a copy of this licence, visit http://creativecommons.org/licenses/by/4.0/.

\section{References}

Aitchison CW (1984) The phenology of winter-active spiders. J Arachnol 12:249-271

Bartczak A, Żylicz T (2014) Willingness to pay for forest cleaning in Poland: Results from a Contingent Valuation survey. Econom Environ 4:137-145

Barthel J (1997) Habitat preferences of Enoplognatha latimana Hippa et Oksala, 1982, and Enoplognatha ovata (Clerck, 1757) (Araneae: Theridiidae) in agricultural landscapes in Southern Bavaria (Germany). In: Żabka M (ed) Proceedings of the 16th European colloquium of arachnology. Wyższa Szkoła Rolniczo-Pedagogiczna, Siedlce

Bartoń K (2016) MuMIn: multi-model inference. R package version 3:23. http://CRAN.Rproject.org/packa ge $=$ MuMIn

Bar-Ziv MA, Subach A, Hirsch-Ionescu A, Belmaker J, Zweifler A, Scharf I (2018) Comparison of wormlions and their immediate habitat under man-made and natural shelters: suggesting factors making wormlions successful in cities. Zoology 130:38-46

Benedict RA, Billeter MC (2004) Discarded bottles as a cause of mortality in small vertebrates. Southeast Nat 3:371-378

Benjamin SP, Zschokke S (2004) Homology, behaviour and spider webs: web construction behaviour of Linyphia hortensis and L. triangularis (Araneae: Linyphiidae) and its evolutionary significance. J Evol Biol 17:120-130

Blandenier G, Bruggisser OT, Rohr RP, Bersier LF (2013) Are phenological patterns of ballooning spiders linked to habitat characteristics? J Arachnol 41:126-132

Buchholz S, Hannig K (2009) Do covers influence the capture efficiency of pitfall traps? Eur J Entomol 106:667-671 
Buchholz S, Jess A-M, Hertenstein F, Schirmel J (2010) Effect of the colour of pitfall traps on their capture efficiency of carabid beetles (Coleoptera: Carabidae), spiders (Araneae) and other arthropods. Eur J Entomol 107:277-280

Buchholz S, Blick T, Hannig K, Kowarik I, Lemke A, Otte V, Scharon J, Schönhofer A, Teige T, von der Lippe M, Seitz B (2016) Biological richness of a large urban cemetery in Berlin. Results of a multitaxon approach. Biodivers Data J 4:e7057

Bultman TL, Uetz GW (1982) Abundance and community structure of forest floor spiders following litter manipulation. Oecologia 55:34-41

Burgess JW (1978) Social behavior in group-living spider species. Symp Zool Soc Lond 42:69-78

Burkman CE, Gardiner MM (2015) Spider assemblages within greenspaces of a deindustrialized urban landscape. Urban Ecosyst 18:793-818

Burnham KP, Anderson DR (2004) Multimodel inference: understanding AIC and BIC in model selection. Sociol Methods Res 33:261-304

Cardoso P, Pekár S, Jocqué R, Coddington JA (2011) Global patterns of guild composition and functional diversity of spiders. PLoS ONE 6:21710

Ceballos G, Ehrlich PR, Dirzo R (2017) Biological annihilation via the ongoing sixth mass extinction signaled by vertebrate population losses and declines. PNAS 114:E6089-E6096

Czaczkes TJ, Bastidas-Urrutia AM, Ghislandi P, Tuni C (2018) Reduced light avoidance in spiders from populations in light-polluted urban environments. Sci Nat 105:64

Czajka M (1963) Unknown facts of the biology of the spider Ero furcata (Villers) (Mimetidae, Araneae). Pol Pis Entomol 33:229-231

Czarnecka M, Poznańska M, Kobak J, Wolnomiejski N (2009) The role of solid waste materials as habitats for macroinvertebrates in a lowland dam reservoir. Hydrobiologia 635:125-135

Dahirel M, Dierick J, De Cock M, Bonte D (2017) Intraspecific variation shapes community-level behavioral responses to urbanization in spiders. Ecology 98:2379-2390

Didham RK, Basset Y, Collins CM, Leather SR, Littlewood NA, Menz MH, Müller J, Packer L, Saunders ME, Schönrogge K, Stewart AJA, Yanoviak SP, Hassall C (2020) Interpreting insect declines: seven challenges and a way forward. Insect Conserv Divers 13:103-114

Eichenberger B, Siegenthaler E, Schmidt-Entling MH (2009) Body size determines the outcome of competition for webs among alien and native sheetweb spiders (Araneae: Linyphiidae). Ecol Entomol $34: 363-368$

Entling W, Schmidt MH, Bacher S, Brandl R, Nentwig W (2007) Niche properties of Central European spiders: shading, moisture and the evolution of the habitat niche. Glob Ecol Biogeogr 16:440-448

Finch OD (2005a) The parasite complex and parasite-induced mortality of spiders (Araneae) in a Central European woodland. J Nat Hist 39:2339-2354

Finch OD (2005b) Evaluation of mature conifer plantations as secondary habitat for epigeic forest arthropods (Coleoptera: Carabidae; Araneae). For Ecol Manag 204:21-34

Finke DL, Denno RF (2002) Intraguild predation diminished in complex-structured vegetation: implications for prey suppression. Ecology 83:643-652

Hale R, Swearer SE (2016) Ecological traps: current evidence and future directions. Proc R Soc B 283:20152647

Hänggi A, Stöckli E, Nentwig W (1995) Lebensräume mitteleuropäischer Spinnen. Charakterisierung der Lebensräume der häufigsten Spinnenarten Mitteleuropas und der mit diesen vergesellschafteten Arten. Miscellanea Faunistica Helvetiae 4:459

Harwood JD, Sunderland KD, Symondson WOC (2003) Web-location by linyphiid spiders: prey-specific aggregation and foraging strategies. J Anim Ecol 72:745-756

Heiling AM (1999) Why do nocturnal orb-web spiders (Araneidae) search for light? Behav Ecol Sociobiol 46:43-49

Heiling AM, Herberstein ME (1999) The importance of being larger: intraspecific competition for prime web sites in orb-web spiders (Araneae, Araneidae). Behaviour 136:669-677

Horváth R, Magura T, Tóthmérész B (2012) Ignoring ecological demands masks the real effect of urbanization: a case study of ground-dwelling spiders along a rural-urban gradient in a lowland forest in Hungary. Ecol Res 27:1069-1077

Hsieh Y-L, Linsenmair KE (2012) Seasonal dynamics of arboreal spider diversity in a temperate forest. Ecol Evol 2:768-777

Johnson JC, Trubl PJ, Miles LS (2012) Black widows in an urban desert: city-living compromises spider fecundity and egg investment despite urban prey abundance. Am Midl Nat 168:333-340

Juarez JG, Garcia-Luna S, Chaves LF, Carbajal E, Valdez E, Avila C, Tang W, Martin E, Barrera R, Hemme RR, Mutebi J-P, Vuong N, Roark BE, Maupin ChR, Badillo-Vargas IE, Hamer GL (2020) Dispersal 
of female and male Aedes aegypti from discarded container habitats using a stable isotope mark-capture study design in South Texas. Sci Rep 10:6803

Kolenda K, Kurczaba K, Kulesza M (2015) Littering as a lethal threat to small animals. Przegl Przyr 26:5362 (in Polish with English summary)

Kolenda K, Salata S, Kujawa K, Kuśmierek N, Smolis A, Kadej M (2020) Deadly trap or sweet home? The case of discarded containers as novelty microhabitats for ants. Glob Ecol Conserv 23:e01064

Kolenda K, Pawlik M, Kuśmierek N, Smolis A, Kadej M (2021) Online media reveals a global problem of discarded containers as deadly traps for animals. Sci Rep 11:267

Korenko S, Pekár S, Honěk A (2010) Predation activity of two winter-active spiders (Araneae: Anyphaenidae, Philodromidae). J Therm Biol 35:112-116

Košulič O, Michalko R, Hula V (2016) Impact of canopy openness on spider communities: implications for conservation management of formerly coppiced oak forests. PLoS ONE 11:e0148585

Kowarik I, Buchholz S, von der Lippe M, Seitz B (2016) Biodiversity functions of urban cemeteries: evidence from one of the largest Jewish cemeteries in Europe. Urban For Urban Green 19:68-78

Kralj-Fišer S, Schneider JM (2012) Individual behavioural consistency and plasticity in an urban spider. Anim Behav 84:197-204

Krumpálová Z, Tuf IH (2013) Circadian rhythms of ground living spiders: Mechanisms of coexistence strategy based on the body size. Pol J Ecol 61:575-586

Laška V, Kopecký O, Růžička V, Mikula J, Véle A, Šarapatka B, Tuf IH (2011) Vertical distribution of spiders in soil. J Arachnol 39:393-398

Lavers JL, Sharp PB, Stuckenbrock S, Bond AL (2020) Entrapment in plastic debris endangers hermit crabs. J Hazard Mat 387:121703

Lee R (ed) (2012) Insects at low temperature. Springer, Berlin

Lowe EC, Wilder SM, Hochuli DF (2016) Persistence and survival of the spider Nephila plumipes in cities: do increased prey resources drive the success of an urban exploiter? Urban Ecosyst 19:705-720

Magura T, Horváth R, Tóthmérész B (2010) Effects of urbanization on ground-dwelling spiders in forest patches, in Hungary. Landsc Ecol 25:621-629

Mammola S, Isaia M, Demonte D, Triolo P, Nervo M (2018) Artificial lighting triggers the presence of urban spiders and their webs on historical buildings. Landsc Urban Plan 180:187-194

Manfrin A, Singer G, Larsen S, Weiß N, van Grunsven RHA, Weiß NS, Wohlfahrt S, Monaghan MT, Hölker F (2017) Artificial light at night affects organism flux across ecosystem boundaries and drives community structure in the recipient ecosystem. Front Environ Sci 5:61

Martin D (1978) Zum Radnetzbau der Gattung Pachygnatha Sund. (Araneae: Tetragnathidae). Mitteilungen aus dem Zoologischen Museum in Berlin 54:83-95

Martyniuk J, Wise DH (1985) Stage-biased overwintering survival of the filmy dome spider (Araneae, Linyphiidae). J Arachnol 13:321-329

Maxwell SL, Fuller RA, Brooks TM, Watson JEM (2016) Biodiversity: the ravages of guns, nets and bulldozers. Nature 536:143-145

McIntyre NE (2000) Ecology of urban arthropods: a review and a call to action. Ann Entomol Soc Am 93:825-835

McKinney ML (2008) Effects of urbanization on species richness: a review of plants and animals. Urban Ecosyst 11:161-176

Milasowszky N, Hepner M, Waitzbauer W, Zulka KP (2015) The epigeic spider fauna (Arachnida: Araneae) of 28 forests in eastern Austria. Biodiversität und Naturschutz in Ostösterreich-BCBEA $1: 135-163$

Möller M, Blick T, Buchholz S (2019) Spinnen der Trockenrasen in und um Berlin-Vielfalt, Verbreitung und Gefährdung. Arachnol Mitt 58:52-61

Montgomery GA, Dunn RR, Fox R, Jongejans E, Leather SR, Saunders ME, Shortall ChR, Tingley MW, Wagner DL (2020) Is the insect apocalypse upon us? How to find out. Biol Conserv 241:108327

Nähring D (1991) Zur Phänologie und Ökologie der Enoplognatha ovate-Gruppe (Araneae: Theridiidae). Carolinea 49:131-133

Nentwig W, Blick T, Bosmans R, Gloor D, Hänggi A, Kropf C (2020) Spiders of Europe. Version 09.2020. https://www.araneae.nmbe.ch. Accessed 1 Sep 2020. 10.24436/1

Niemelä J, Pajunen T, Haila Y, Punttila P, Halme E (1994) Seasonal activity of boreal forest-floor spiders (Araneae). J Arachnol 22:23-31

Oxbrough A, Irwin S, Kelly TC, O'Halloran J (2010) Ground-dwelling invertebrates in reforested conifer plantations. For Ecol Manag 259:2111-2121

Oxford GS (1992) Enoplognatha ovata and E. latimana: a comparison of their phenologies and genetics in Norfolk populations. Bull Br Arachnol Soc 9:13-18 
Pearce JL, Venier LA, Eccles G, Pedlar J, McKenney D (2004) Influence of habitat and microhabitat on epigeal spider (Araneae) assemblages in four stand types. Biodivers Conserv 13:1305-1334

Pekár S (2002) Differential effects of formaldehyde concentration and detergent on the catching efficiency of surface active arthropods by pitfall traps. Pedobiologia 46:539-547

Persons MH, Rypstra AL (2001) Wolf spiders show graded antipredator behavior in the presence of chemical cues from different sized predators. J Chem Ecol 27:2493-2504

Piano E, Souffreau C, Merckx T, Baardsen LF, Backeljau T et al. (2020) Urbanization drives cross-taxon declines in abundance and diversity at multiple spatial scales. Glob Chang Biol 26:1196-1211

Poeta G, Romiti F, Battisti C (2015) Discarded bottles in sandy coastal dunes as a threat for macroinvertebrate populations: first evidence of trap effect. Vie Milieu 65:125-127

Prasifka JR, Lopez MD, Hellmich RL, Lewis LC, Dively GP (2007) Comparison of pitfall traps and litter bags for sampling ground-dwelling arthropods. J Appl Entomol 131:115-120

Prestwich KN (1977) The energetics of web-building in spiders. Comp Biochem Physiol A Mol Integr Physiol 3:321-326

R Core Team (2018) R: a language and environment for statistical computing. R Foundation for Statistical Computing, Vienna. https://www.R-project.org/

Riechert SE (1974) Thoughts on the ecological significance of spiders. Bioscience 24:352-356

Riechert SE, Hall RF (2000) Local population success in heterogeneous habitats: reciprocal transplant experiments completed on a desert spider. J Evol Biol 13:541-550

Riecken U (1999) Effects of short-term sampling on ecological characterization and evaluation of epigeic spider communities and their habitats for site assessment studies. J Arachnol 27:189-195

Roberts MJ (1987) The spiders of Great Britain and Ireland, vol 2: Linyphiidae and check list. Harley Books Colchester, England

Roman L, Hardesty BD, Leonard GH, Pragnell-Raasch H, Mallos N, Campbell I, Wilcox C (2020) A global assessment of the relationship between anthropogenic debris on land and the seafloor. Environ Pollut $264: 114663$

Roume A, Ouin A, Raison L, Deconchat M (2011) Abundance and species richness of overwintering ground beetles (Coleoptera: Carabidae) are higher in the edge than in the centre of a woodlot. Eur J Entomol 108:615-622

Rybak J (2007) Structure and function of the web of Bathyphantes simillimus (Araneae: Linyphiidae) in an isolated population in the Stołowe Mountains, SW Poland. Bull Br Arachnol Soc 14:33-38

Samu F, Sunderland KD, Topping CJ, Fenlon JS (1996) A spider population in flux: selection and abandonment of artificial web-sites and the importance of intraspecific interactions in Lepthyphantes tenuis (Araneae: Linyphiidae) in wheat. Oecologia 106:228-239

Samu F, Szirányi A, Kiss B (2003) Foraging in agricultural fields: local 'sit-and-move' strategy scales up to risk-averse habitat use in a wolf spider. Anim Behav 66:939-947

Samu F, Jozsa Z, Csànyi E (2004) Spider web contamination of house facades: habitat selection of spiders on urban wall surfaces. In: Samu F, Szinetàr C (eds) European Arachnology 2002. Plant Protection Institute and Berzsenyi College, Budapest, pp 351-356

Sattler T, Duelli P, Obrist MK, Arlettaz R, Moretti M (2010) Response of arthropod species richness and functional groups to urban habitat structure and management. Landsc Ecol 25:941-954

Scharff N, Coddington JA, Griswold CE, Hormiga G, De Place BP (2003) When to quit? Estimating spider species richness in a northern European deciduous forest. J Arachnol 31:246-273

Schmidt MH, Clough Y, Schulz W, Wetsphalen A, Tscharntke T (2006) Capture efficiency and preservation attributes of different fluids in pitfall traps. J Arachnol 34:159-162

Sol D, Bartomeus I, González-Lagos C, Pavoine S (2017) Urbanisation and the loss of phylogenetic diversity in birds. Ecol Lett 20:721-729

Stánska M, Hajdamowicz I, Żabka M (2002) Epigeic spiders of alder swamp forests in Eastern Poland. In: Toft S, Scharff N (eds) European Arachnology 2000. Aarhus University Press, Århus, pp 191-197

Stańska M, Stański T, Gładzka A, Bartos M (2016) Spider assemblages of hummocks and hollows in a primeval alder carr in the Białowieża National Park-effect of vegetation structure and soil humidity. Pol J Ecol 64:564-577

StatSoft Inc. (2014) STATISTICA (data analysis software system), version 12. http://www.statsoft.com

Stratton GE, Suter RB, Miller PR (2004) Evolution of water surface locomotion by spiders: a comparative approach. Biol J Linn Soc Lond 81:63-78

Toft S (1987) Microhabitat identity of two species of sheet-web spiders: field experimental demonstration. Oecologia 72:216-220

Toft S (1998) Interference by web take-over in sheet-web spiders. In: Haupt J (Ed) Proceedings of the XI. European Arachnological Colloquium. Technische Universiät Berlin, Berlin 
Topping CJ (1993) Behavioural responses of three linyphiid spiders to pitfall traps. Entomol Exp Appl 68:287-293

Topping CJ, Sunderland KD (1992) Limitations to the use of pitfall traps in ecological studies exemplified by a study of spiders in a field of winter wheat. J Appl Ecol 29:485-491

Trubl P, Gburek T, Miles L, Johnson J (2012) Black widow spiders in an urban desert: population variation in an arthropod pest across metropolitan Phoenix, AZ. Urban Ecosyst 15:599-609

Tuomainen U, Candolin U (2011) Behavioural responses to human-induced environmental change. Biol Rev 86:640-657

Turnbull AL (1973) Ecology of the true spiders (Araneomorphae). Annu Rev Entomol 18:305-348

Uetz GW, Unzicker JD (1976) Pitfall trapping in ecological studies of wandering spiders. J Arachnol 3:101-111

Wagner JD, Toft S, Wise DH (2003) Spatial stratification in litter depth by forest-floor spiders. J Arachnol 31:28-39

Wetter MB, Wernisch B, Toft S (2012) Test for attraction to prey and predator avoidance by chemical cues in spiders of the beech forest floor. Arachnol Mitt 43:84-89

Wise DH (1993) Spiders in ecological webs. Cambridge University Press, Cambridge

Work TT, Buddle CM, Korinus LM, Spence JR (2002) Pitfall trap size and capture of three taxa of litterdwelling arthropods: implications for biodiversity studies. Environ Entomol 31:438-448

World Spider Catalog (2021) World Spider Catalog. Version 22.0. Natural History Museum Bern. http:// wsc.nmbe.ch. Accessed 1 Feb 2021

Wright RL, Coyle FA (2000) Habitat distribution, life history and behaviour of Neriene species in the Great Smoky Mountains National Park (Araneae, Linyphiidae). Bull Br Arachnol Soc 11:293-304

Youngsteadt E, Ernst AF, Dunn RR, Frank SD (2016) Responses of arthropod populations to warming depend on latitude: evidence from urban heat islands. Glob Change Biol 23:1436-1447

Publisher's Note Springer Nature remains neutral with regard to jurisdictional claims in published maps and institutional affiliations.

\section{Authors and Affiliations}

\section{Krzysztof Kolenda ${ }^{1} \mathbb{D} \cdot K$ Konrad Wiśniewski ${ }^{\mathbb{D}} \cdot \mathrm{Krzysztof} \mathrm{Kujawa}^{3} \mathbb{D} \cdot$ Natalia Kuśmierek ${ }^{4}$ (D) Adrian Smolis $^{5}$ (D) Marcin Kadej $^{5}$}

1 Department of Evolutionary Biology and Conservation of Vertebrates, University of Wrocław, Sienkiewicza 21, 50-335 Wrocław, Poland

2 Department of Zoology and Animal Physiology, Institute of Biology and Earth Sciences, Pomeranian University in Słupsk, Arciszewskiego 22b, 76-200 Słupsk, Poland

3 Institute for Agricultural and Forest Environment, Polish Academy of Sciences, Bukowska 19, 60-809 Poznań, Poland

4 Department of Parasitology, University of Wrocław, Przybyszewskiego 63, 51-148 Wrocław, Poland

5 Department of Invertebrate Biology, Evolution and Conservation, University of Wrocław, Przybyszewskiego 65, 51-148 Wrocław, Poland 